Case Report

\title{
Survey on Current Situation of Chinese College Students' Teaching Evaluation Cognition
}

\author{
Zhuang Jing, Guo Qian \\ Department of Information, Beijing Wuzi University, Beijng, China \\ Email address: \\ nihaojing89@sina.com (Zhuang Jing),guoqian561@126.com (Guo Qian)
}

\section{To cite this article:}

Zhuang Jing, Guo Qian. Survey on Current Situation of Chinese College Students' Teaching Evaluation Cognition. American Journal of Applied Psychology. Vol. 5, No. 4, 2016, pp. 17-21. doi: 10.11648/j.ajap.20160504.11

Received: August 3, 2016; Accepted: August 15, 2016; Published: September 2, 2016

\begin{abstract}
Teaching evaluation is a teaching management method used by many colleges in China, and the evaluation behavior of college students directly affects the fairness and objectivity of teaching evaluation results. The survey shows that college students lack of the cognition of teaching evaluation and they generally don't understand the function of teaching evaluation, which has large arbitrariness and easy to be affected by the strict degree of teachers and the difficulty degree of courses, thus it is lack of objectivity.
\end{abstract}

Keywords: Teaching Evaluation Cognition, College Students, Survey

\section{Introduction}

Teaching evaluation is a teaching management method used by great number of colleges in China, and some colleges take the teaching evaluation results as a basis for rewards and punishments, promotion and demotion, and the employment of people. The authenticity and objectivity of teaching evaluation result are the critical factors to decide whether the teaching evaluation can be used as an effective means to manage teacher. The cognition of teaching evaluation directly affects the teaching evaluation behavior of students, correct cognition will guide college students to rationally participate in teaching evaluation, while inadequate cognition will mislead the teaching evaluation behavior, thus the teaching evaluation results cannot effectively reflect the teaching process, nor as a basis for teacher management. This paper analyzes the current situation of Chinese college students' cognition of teaching evaluation from three aspects: the cognition of teaching evaluation system, the cognition of teaching function and the cognition of teaching evaluation pressure.

This paper takes the college students as research object, using face-to-face interview and the network survey to collect first-hand information, to study college students' cognition of teaching evaluation and teaching evaluation behavior. 1500 questionnaires were issued to three Municipal colleges' in students Beijing from February to April 2016, there were 1431 valid questionnaires and the valid rate was $95.4 \%$. The composition of sample schools: college A accounted for $26.83 \%$, college B accounted for $37.95 \%$, college $\mathrm{C}$ accounted for $35.22 \%$. The investigation uses the cognition of teaching evaluation table (Table 1) to measure students' teaching evaluation cognition, the scale consists of three subscales: cognition of teaching evaluation system subscale, cognition of teaching evaluation function subscale, cognition of teaching evaluation pressure. Total scale's coefficient $\alpha$ is 0.807 , which belongs to high reliability; the coefficient $\alpha$ of the cognition of teaching evaluation function subscale is 0.687 , which belongs to the sound reliability; the coefficient $\alpha$ of the cognition of teaching evaluation system subscale is 0.744 , which belongs to high reliability; the coefficient $\alpha$ of the cognition of teaching evaluation pressure subscale is 0.804 , which indicates the reliability is very high. Overall, the scale has a sound reliability. 
Table 1. The composition of the cognition of teaching evaluation system subscale.

\begin{tabular}{|c|c|c|c|}
\hline Subscale & Item & Subscale & Item \\
\hline \multirow{2}{*}{$\begin{array}{l}\text { The } \\
\text { cognition of } \\
\text { teaching } \\
\text { evaluation } \\
\text { system } \\
\text { subscale }\end{array}$} & $\begin{array}{l}\text { A1 I can clearly remember the school } \\
\text { teaching evaluation indicators } \\
\text { A2 I know the calculation method of } \\
\text { teaching evaluation score } \\
\text { A3 I know the school teaching evaluation } \\
\text { problem has been revised. }\end{array}$ & $\begin{array}{l}\text { The cognition of } \\
\text { teaching evaluation } \\
\text { function subscale }\end{array}$ & $\begin{array}{l}\text { B1 The results of teaching evaluation can be used as the basis for } \\
\text { teacher's promotion } \\
\text { B2 The evaluation of teaching quality can encourage teachers to } \\
\text { improve the teaching quality } \\
\text { B3 Teaching evaluation scores can truly reflect the teaching level }\end{array}$ \\
\hline & $\begin{array}{l}\text { A4 All courses can use the same teaching } \\
\text { evaluation indicators }\end{array}$ & $\begin{array}{l}\text { The cognition of } \\
\text { teaching evaluation } \\
\text { pressure }\end{array}$ & $\begin{array}{l}\text { C1 The difficulty of courses is greater, the evaluation score of the } \\
\text { teacher is lower } \\
\text { C2 The teachers are stricter, teachers' evaluation score is lower }\end{array}$ \\
\hline
\end{tabular}

\section{The Cognition Status of Teaching Evaluation System}

The cognition of the teaching evaluation system reflects the students' understanding degree of the content and evaluation methods of the teaching evaluation system. If the students are very clear about the teaching evaluation indicators, the calculation methods, and pay attention to the adjustment of teaching evaluation of the school, which indicates that the students have a higher cognition degree of teaching evaluation system. The measurement results of teaching evaluation system's cognition scale shows that the understanding of college students to teaching evaluation system is insufficient, students in high grade have the lowest cognition degree of teaching evaluation system, besides, the cognition degrees of teaching evaluation system in different schools are significantly differ from each other.

Firstly, college students know little about teaching evaluation system. Teaching evaluation is an activity that students participate in every semester, but students' cognition of teaching evaluation system is not ideal. Only $4.4 \%$ of the students know the content of the teaching evaluation, $6.5 \%$ of them know that the school teaching evaluation indicators have been adjusted, and $4 \%$ of them know the calculation method of teaching evaluation scores. It seems that college students do not exactly know the content and evaluation methods of the teaching evaluation system.

Secondly, school has a significant impact on the cognition results of teaching evaluation system. Table 2 shows the significant level of the four items teaching evaluation system cognition subscale and the corresponding chi-square value of school is less than 0.05 , and the students in different schools have different cognition degree of teaching evaluation system. The differences between schools mainly reflect that the overall cognition degree of teaching evaluation of students in college B is better than that of college A and C. College B students' memory degree of the teaching evaluation content is higher than that of college C, $25 \%$ students of college B can remember their school's teaching evaluation indicators, while only $14 \%$ students of college C can remember the problem; College $\mathrm{B}$ students are more clear about the calculation method of teaching evaluation score than college A and college C, 18\% students of college $\mathrm{B}$ know the calculation method of school teaching evaluation, while only $12 \%$ and $10 \%$ students of college A and college C know about it respectively; 25\% students of colleges B know about the modification of teaching evolution of their school, while only $10 \%$ students of college A and college $\mathrm{C}$ know about it.

Table 2. Chi-square test of the cognition of school, grade and teaching evaluation system subscale.

\begin{tabular}{|c|c|c|c|c|c|c|}
\hline \multirow{2}{*}{ The cognition of teaching evaluation system subscale } & \multicolumn{3}{|l|}{ College } & \multicolumn{3}{|l|}{ Grade } \\
\hline & Chi-square value & df & P-value & Chi-square value & df & P-value \\
\hline A1 & 42.653 & 8 & 0.000 & 82.606 & 20 & 0.000 \\
\hline A2 & 48.377 & 8 & 0.000 & 62.705 & 20 & 0.000 \\
\hline A3 & 27.581 & 8 & 0.001 & 78.234 & 20 & 0.000 \\
\hline A4 & 26.834 & 8 & 0.001 & 61.212 & 20 & 0.000 \\
\hline
\end{tabular}

Thirdly, high grade students can clearly realize their own understanding of the teaching evaluation system is not high. Although the students in higher grade participate in more teaching evaluation activities than students in lower grade, their cognition degree of teaching evaluation system doesn't increases accordingly, however, there is a decline. Table 2 shows the significant level of the corresponding chi-square value of four items and grade is less than 0.05 in the teaching evaluation system's cognition subscale. The specific differences of the cognition of teaching evaluation system by students in different grades show that: $23.1 \%$ of seniors think they are unable to remember the content of teaching evaluation, the number of students are significantly higher than other grades; $48.7 \%$ seniors think they do not know the calculation method of teaching evaluation score, which are higher for $10 \%$ than other grades; $41.0 \%$ seniors do not know that the revision teaching evaluation problems in their school, which are higher than other grades for nearly $20 \%$.

\section{Cognition Status of Teaching Evaluation Function}

The cognition of teaching evaluation function reflects that what functions of teaching evaluation results in teaching operation and management by students. Students realize that 
teaching evaluation is an important means to improve teaching quality and teaching management, which indicates that students have a higher cognition degree of teaching evaluation function. The survey results show that most of the students believe that teaching evaluation cannot supervise well in teaching management.

Firstly, as the approach of teaching management, teaching evaluation faces the challenge of how to collect the real data. Although the students basically agree with taking the teaching evaluation as an approach to evaluate teachers' teaching quality, there are still nearly a third of the students believe that the authenticity of teaching evaluation scores are need to be verified. $38.6 \%$ students agree that teaching evaluation can encourage teachers to improve their teaching quality; only $24.5 \%$ of them believe that the teaching evaluation score can truly reflect the teacher's teaching level, and the proportion of non-consent is as high as $31.4 \%$.

Secondly, the authenticity of teaching evaluation scores influences the realization effect of teaching evaluation function. When students think that the teaching evaluation scores cannot reflect the teacher's teaching level, then the teaching evaluation results cannot be used as the basis for teaching management. Table 3 shows the significant level of the corresponding three items and school chi-square test is less than 0.05 , namely, the school has a certain impact on students' cognition of teaching evaluation function. There is highest proportion of college A students who believe that the teaching evaluation score is not true, some students believe that teaching evaluation plays a little role in the teaching management. $13.3 \%$ students in college A strongly disagree that teaching evaluation score can truly reflect teachers' teaching level, which are more than the other two colleges for $5 \% ; 22 \%$ of them disapprove that the teaching evaluation can encourage teachers to improve their teaching quality, the number is significantly higher than that of the other two colleges for $5 \% .7 .2 \%$ students of colleges B strongly agree that the teaching evaluation score can truly reflect teachers' teaching level, there are $11.6 \%$ students agree to take the teaching evaluation results as a basis for teachers' promotion, the number is significantly higher than that of the other two colleges. The cognition of teaching evaluation function by college A and college B students fully confirms the authenticity of the teaching evaluation scores will affect the effectiveness of teaching evaluation function.

Thirdly, more senior students believe teaching evaluation fails to play its due function, and the teaching evaluation scores is depart from teachers' teaching level. Chi square test results in table 3 shows that, the significance level of grade and three corresponding items of teaching evaluation function subscale is less than 0.05 , which indicates that the grade has a significant impact on the cognition of teaching evaluation function, the number of students in high grade who think that teaching evaluation fails to give full play its function is obviously more than that in low grade, the proportion of seniors who agree teaching evaluation facilitates to improve teaching quality accounted for $40 \%$, the agreement rate is lower than other grades for $10 \%$. The proportion of senior students who opposite that teaching evaluation scores can truly reflect teachers' teaching level is $40 \%$, which is higher than other grades for nearly $10 \%$. When students think that teaching evaluation results has no effect on school teaching management, with the participation times of teaching evaluation increases, they gradually lost enthusiasm for teaching evaluation, arbitrary scoring phenomenon will increase. Therefore, the teaching evaluation score is very difficult to reflect teachers' teaching level.

Table 3. Chi-square test of school, grade and teaching evaluation function cognition subscale.

\begin{tabular}{|c|c|c|c|c|c|c|}
\hline \multirow{2}{*}{ The cognition of teaching evaluation system subscale } & \multicolumn{3}{|l|}{ College } & \multicolumn{3}{|l|}{ Grade } \\
\hline & Chi-square value & df & P-value. & Chi-square value & df & P-value \\
\hline B1 & 23.922 & 8 & 0.002 & 75.904 & 20 & 0.000 \\
\hline B2 & 27.061 & 8 & 0.001 & 48.068 & 20 & 0.000 \\
\hline B3 & 34.158 & 8 & 0.000 & 61.300 & 20 & 0.000 \\
\hline
\end{tabular}

\section{The Current Status of Teaching Evaluation Pressure}

Teaching evaluation pressure mainly reflects the teacher's strict degree and the course's difficulty degree will give students a certain degree of learning pressure, the learning pressure will bring a certain impact on teaching learning. Students believe that the difficulty of courses is greater, the teacher is stricter, they will perceive greater learning pressure, and the impact of transmission to the teaching evaluation is greater. The survey shows that learning pressure has a negative effect on teaching evaluation, when students think that they suffer large pressure of course or teacher, some of them will release their negative feelings through the teaching evaluation, which causes the distortion of the teaching evaluation result.

Firstly, 20\% students think that the difficulty of the course and the teacher's strict degree will influence the result of teacher evaluation. Although $40 \%$ students are against it, there are still $19.7 \%$ students in favor of the course's difficulty is greater, teacher evaluation score is lower, $24.4 \%$ students agree that the teacher is more strict, teaching evaluation score is lower. It indicates that the pressure of teachers and course will have a certain impact on teaching evaluation result, what's more, the influence of teacher's strict degree is bigger than that of course.

Secondly, students have different attitude towards "strict teacher" in teaching evaluation, and Science and Engineering major students in favor of "strict teacher". Chi square test in 
table 4 shows that the significant level of the school and the two corresponding items of teaching evaluation pressure subscale is less than 0.05 , namely, school has a significant impact on the teaching evaluation. The major subject of college A is Economy \& Management, the major subject of college $\mathrm{C}$ and college $\mathrm{B}$ is Science and Engineering, professional background of different schools has certain effect on teaching evaluation pressure, students in college A are more conflict the strict teacher, while students in college B and $\mathrm{C}$ are easier to accept the strict teacher. Three college students approve that the proportion of the more difficulty of course and lower teaching evaluation score is consistent, which maintains around $20 \%$, but they have significantly different views in stricter of teacher and lower evaluation score, college A students who agree stricter of teacher and lower evaluation score accounted for $28 \%$, which is significantly higher than that of the other two colleges.

Thirdly, more than $80 \%$ of the freshmen and sophomores can correctly deal with the relationship between learning pressure and teaching evaluation. Chi square test in table shows that the significant level of the grade and two corresponding problems of teaching evaluation pressure subscale is less than 0.05 , namely, the grade has a significant impact on teaching evaluation pressure. The proportion of freshmen and sophomores who agree the more difficulty of course the lower teaching evaluation score is significantly lower than that of juniors and senior students; $3 \%$ freshmen and sophomores very agree that stricter of the teacher and lower teaching evaluation score, the number is significantly less than that of junior and senior students. The learning pressure tolerance of freshman and sophomores is significantly higher than that of junior and senior students, they are more rational to deal with the learning pressure and teaching evaluation, only $15 \%$ of them will choose to give lower teaching evaluation score to release their learning pressure; the junior and senior students, otherwise, about $25 \%$ of them will choose this irrational way release their learning pressure.

Table 4. Chi-square test of school, grade and teaching evaluation function cognition subscale.

\begin{tabular}{|c|c|c|c|c|c|c|}
\hline \multirow{2}{*}{ The cognition of teaching evaluation pressure subscale } & \multicolumn{3}{|l|}{ School } & \multicolumn{3}{|l|}{ Grade } \\
\hline & Chi-square value & df & P-value & Chi-square value & df & P-value \\
\hline $\mathrm{C} 1$ & 23.507 & 8 & .001 & 48.838 & 20 & .001 \\
\hline $\mathrm{C} 2$ & 25.893 & 8 & .000 & 52.991 & 20 & .000 \\
\hline
\end{tabular}

\section{Conclusion}

From the above investigation and analysis we can see that there is a large deviation of college students' cognition of teaching evaluation in China, more than half of the students don't know the contents and functions of the teaching evaluation, they are easily to be affected by the course's difficulty degree and teacher's severity degree when participating in the teaching evaluation, which seriously influences the effectiveness of teaching evaluation results.

\section{References}

[1] Ana-Belén López-Cámara, Ignacio González-López, Carlota de León-Huertas. Exploratory factor analysis to construct a model of university teaching evaluation indicators / Un análisis factorial exploratorio para la construcción de un modelo de indicadores de evaluación docente universitaria [J]. Cultura y Educación, 2015, 272:

[2] Kite Mary E., Subedi Prabin Chandra, Bryant-Lees Kinsey B. Students' Perceptions of the Teaching Evaluation Process [J]. Teaching of Psychology, 2015, 424:.

[3] Loertscher, David V. The Framework for Teaching Evaluation Instrument, 2013 Edition: The Newest Rubric Enhancing the Links to the Common Core State Standards, with Clarity of Language for Ease of Use and Scoring [J]. Teacher Librarian, 2014, 414:.
[4] Chih-Yung Chen, Jih-Fu Tu, Stephen D. Prior. An Implementation Model of Teaching Evaluation Questionnaire System Based on Cloud Computing [J]. Mathematical Problems in Engineering, 2014, 2014:.

[5] Li Na, Lin Cong An Empirical Study PhD Classroom Teaching Evaluation - A Case Study of the University of W and analysis [J] Based Higher Education Management, 05, 2013, P106-111

[6] Huadi Wang. Physical Education Teaching Evaluation System based on Analytic Hierarchy Process Model [J]. International Journal of Digital Content Technology and its Applications, 2013, 76:

[7] Sanjing Geng, Lihui Huang. Research of Association Rule Mining in College Teaching Evaluation [J]. International Journal of Digital Content Technology and its Applications, 2013, 77:

[8] Wei Lin. The Study of Computer Teaching Evaluation in Higher Education in China with Hesitant Fuzzy Information [J]. Journal of Convergence Information Technology, 2013, 89:.

[9] Zheng Xiaomei. A Novel Method for Foreign Language Teaching Evaluation Based on Feature Selection [J]. International Journal of Digital Content Technology and its Applications, 2013, 72:.

[10] Ma Yong. Advanced Mathematics Teaching Evaluation Model base on Decision Tree Algorithm [J]. Journal of Convergence Information Technology, 2013, 89:.

[11] Yanli Liang. Research of Multimedia Interactive English Teaching Evaluation System under Network Environment [J]. International Journal of Advancements in Computing Technology, 2013, 52: 
Biography

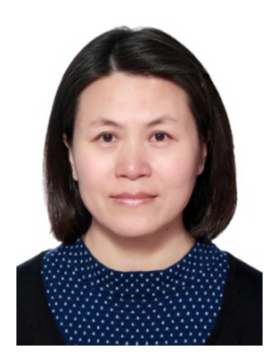

Zhuang Jing, Department of Information, Beijing Wuzi University, Beijng, China, female, native of Shanghai, born in 1966, $\mathrm{PhD}$ graduated from Renmin University of China, associate professor at Beijing Materials Institute, research statistical forecasting.

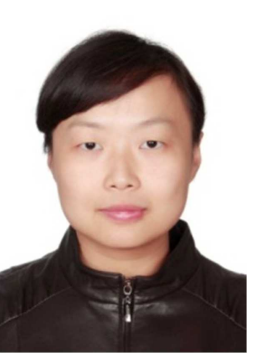

Guo Qian, Department of Information, Beijing Wuzi University, Beijng, China, female, native of Henan Province, born in 1979, PhD graduated from Renmin University of China, associate professor at Beijing Wuzi University, research direction of economic statistics. 